\title{
Thermal Empirical Equations for Post-Flashover Compartment Fires
}

\author{
MIAO WU, and W.K. CHOW \\ Research Centre for Fire Engineering \\ Department of Building Services Engineering \\ Area of Strength : Fire Safety Engineering \\ The Hong Kong Polytechnic University, Hong Kong, China
}

\begin{abstract}
Many useful correlation equations derived for estimating the heat release rate are believed to be adequate in fire engineering application. However, heat release rates in deriving those equations were mainly based on estimating mass loss rate of fuel. Flashover in a compartment fire had been studied experimentally on gasoline pool fires with results on heat release rate reported earlier. Transient heat release rates were measured by oxygen consumption calorimetry. The gas temperature curves at different locations in the room were measured instantaneously. Correlation equations on heat release rates with gas temperature reported in the literature will be reviewed and justified with the experimental results. It was observed that heat release rate estimated were lower than the experimental measurement.
\end{abstract}

KEYWORDS: post-flashover, compartment fires, empirical equation.

\section{NOMENCLATURE LISTING}

\begin{tabular}{|c|c|c|c|}
\hline$A_{w}$ & total wall area of compartment (m) & $\dot{q}_{L}$ & heat lost rate $(\mathrm{kW})$ \\
\hline$A_{v}$ & area of ventilation opening $(\mathrm{m})$ & $T_{f}$ & fire temperature $\left({ }^{\circ} \mathrm{C}\right)$ \\
\hline$C_{p}$ & specific heat capacity of gas $(\mathrm{J} / \mathrm{kg} \cdot \mathrm{K})$ & $T_{\text {fmax }}$ & maximum fire temperature measured $\left({ }^{\circ} \mathrm{C}\right)$ \\
\hline$h_{v}$ & height of ventilation opening (m) & $T_{o}$ & air temperature of hall $\left({ }^{\circ} \mathrm{C}\right)$ \\
\hline$m_{A}$ & $\begin{array}{l}\text { constant related to total heat release rate } \\
\left(\mathrm{kW} \cdot{ }^{\circ} \mathrm{C}^{-1}\right)\end{array}$ & $t_{B}$ & burning time of fuel (s) \\
\hline$m_{A L}$ & constant related to heat lost $\left(\mathrm{kW} \cdot{ }^{\circ} \mathrm{C}^{-1}\right)$ & $V_{f}$ & ventilation factor $\left(\mathrm{m}^{5 / 2}\right)$ \\
\hline$m_{A V}$ & $\begin{array}{l}\text { constant related to ventilation provision } \\
\text { heat lost }\left(\mathrm{kW} \cdot{ }^{\circ} \mathrm{C}^{-1}\right)\end{array}$ & $W_{v}$ & width of ventilation opening $(\mathrm{m})$ \\
\hline$m_{f}$ & slope of fitted line & Greek & \\
\hline$\dot{m}_{a}$ & $\begin{array}{l}\text { air flow rate through the ventilation } \\
\text { opening }\left(\mathrm{kg} \cdot \mathrm{s}^{-1}\right)\end{array}$ & $\Delta h_{c}$ & $\begin{array}{l}\text { effective calorific value of fuel } \\
\left(\mathrm{MJ} \cdot \mathrm{kg}^{-1}\right)\end{array}$ \\
\hline$\dot{m}_{p}$ & fuel mass loss rate $\left(\mathrm{kg} \cdot \mathrm{s}^{-1}\right)$ & $\sigma$ & Stefan-Boltzman constant \\
\hline$\dot{q}$ & heat release rate of fire $(\mathrm{kW})$ & $\varepsilon_{f}$ & gas emissivity \\
\hline & maximum heat release rate measured $(\mathrm{kW})$ & & \\
\hline
\end{tabular}

\section{INTRODUCTION}

Big post-flashover [1] building fires were observed in big cities in the Far East. Taking Hong Kong [2] as an example, these big fires occurred in old factory buildings built 40 years ago. Possible reasons are firstly some factories for light plastics industry are starting to move back to Hong Kong. Secondly, such industrial buildings are now functioning as mini-warehouses. These old buildings are used as storage areas with much more combustibles. However, such buildings are not regarded as warehouses without adequate fire protection. Three big post-flashover fires occurred had already killed four firemen in the past few years. Therefore, flashover should be studied properly, particularly with so many modern materials used.

Works on flashover phenomenon reported in the literature mainly based on estimating air flow rate across opening in the room fire. These included pioneer works by Kawagoe [3] on hydrostatic models to give a relation on ventilation factor. Many other works followed [4-6] with experimental data reported in the 
literature on deriving, assessing or verifying useful design empirical equations. Although there had been many studies on flashover fire, the understanding is still on thermal aspects. This is because firstly there are thousands of intermediate combustion chemical reactions while burning the fuel. Secondly, turbulent flow in air mixing is difficult to model. Thirdly, thermal radiation heat fluxes cannot be calculated accurately without measuring empirical parameters. In those works, heat release rate used to be assessed by the fuel mass loss rate. Flashover was commonly determined by observing whether flame came out of the doors. Results might be different if the heat release rates are measured oxygen consumption calorimetry, e.g. Ref. [7].

A series of full-scale burning tests on flashover in compartment fires with heat release rate measured by oxygen consumption calorimetry were performed and reported [8]. Results were applied to assess the correlation equations on the minimum heat release to flashover. Those results will be used further in this paper on studying thermal aspects of post-flashover fires. Transient gas temperatures measured at different locations of the room will be used to justify the transient heat release rate measured by oxygen consumption. Results are then compared with empirical equations reported in the literature.

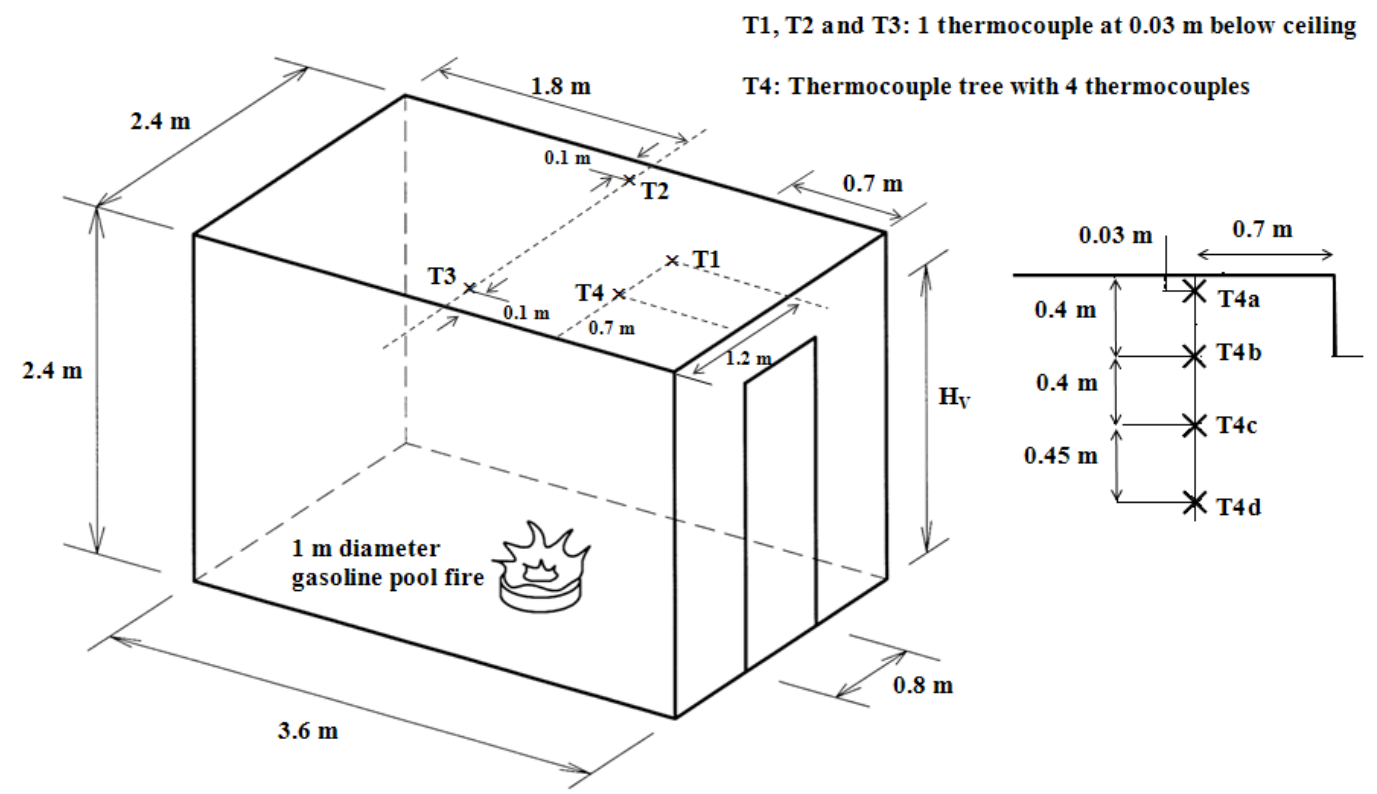

Fig. 1. The room calorimeter.

\section{FULL-SCALE BURNING TESTS}

A room calorimeter of length $3.6 \mathrm{~m}$, width $2.4 \mathrm{~m}$ and height $2.4 \mathrm{~m}$ as shown in Fig. 1 was constructed with bricks in a full-scale burning hall at Northeast China. A door with fixed width $W_{v}$ of $0.8 \mathrm{~m}$ but varying height $h_{v}$ from $0.9 \mathrm{~m}$ to $1.95 \mathrm{~m}$ was provided. Ventilation factor can be adjusted from $0.68 \mathrm{~m}^{5 / 2}$ to $2.18 \mathrm{~m}^{5 / 2}$. Six sets of tests, labeled as A1 to A6 were carried out [8] with different values of $H_{v}$ shown in Table 1. Tests A1 to A6 were for rectangular openings with height longer than the width. Opening arrangements for the tests are shown in Fig. 2.

A gasoline pool fire of $1 \mathrm{~m}$ diameter was placed at the room centre. The fuel volume was $1500 \mathrm{~cm}^{3}$ to give a burning period $t_{B}$ varying from $422 \mathrm{~s}$ to $621 \mathrm{~s}$ for tests with different ventilation provisions. Air temperature of the experimental hall $T_{o}$ varied from $15{ }^{\circ} \mathrm{C}$ to $16^{\circ} \mathrm{C}$.

There are 7 thermocouples with 1 each at T1, T2 and T3, and 4 labeled as T4a to T4d at T4 as in Fig. 1. Transient gas temperatures were measured and shown in Fig. 3. Type-K thermocouple of $3 \mathrm{~mm}$ diameter able to stand up to $1000{ }^{\circ} \mathrm{C}$ was used for measuring post-flashover fire temperatures. 
Transient heat release rates $\dot{q}$ in the room fire were measured by the oxygen consumption method with results shown in Fig. 4. Uncertainty of the heat release rate was calculated to be within $10 \%$ as reported earlier.

Flashover was determined by when flames coming out of the opening. From the transient curve on $\dot{q}$, the minimum heat release rate was determined by two criteria: gas temperature next to ceiling at $600{ }^{\circ} \mathrm{C}$ or radiative heat flux of $20 \mathrm{~kW} \cdot \mathrm{m}^{-2}$. The minimum heat release rate for flashover were then taken out on justifying correlation equations on the minimum heat release rates for flashover with the ventilation factor by Babrauskas [5,6], Thomas et al. [9,10], Quintiere et al. [11,12] and Morgan [13]. It was observed that experimental results lying close to the equation derived by Babrauskas [5,6], within the range of $30 \%$ to $70 \%$ of air intake rate for stoichiometric combustion. This set of equations $[5,6]$ is now taken out and justified on temperature estimation for post-flashover fires in this presentation.

Table 1. Summary of results.

\begin{tabular}{|c|c|c|c|c|c|c|c|c|c|c|c|c|c|}
\hline \multirow{2}{*}{\multicolumn{3}{|c|}{$\begin{array}{c}\text { Test number } \\
\text { Parameters } \\
\text { Ventilation height } \\
h_{v} / \mathrm{m}\end{array}$}} & A1a & Alb & $\mathrm{A} 2 \mathrm{a}$ & $\mathrm{A} 2 \mathrm{~b}$ & A3a & $\mathrm{A} 3 \mathrm{~b}$ & $\mathrm{~A} 4 \mathrm{a}$ & $\mathrm{A} 4 \mathrm{~b}$ & A5a & A5b & A6 \\
\hline & & & \multicolumn{2}{|c|}{1.95} & \multicolumn{2}{|c|}{1.8} & \multicolumn{2}{|c|}{1.6} & \multicolumn{2}{|c|}{1.45} & \multicolumn{2}{|c|}{1.2} & 0.9 \\
\hline \multicolumn{3}{|c|}{$\begin{array}{l}\text { Height of vent } \\
\text { bottom above } \\
\text { floor / m }\end{array}$} & \multicolumn{2}{|c|}{0} & \multicolumn{2}{|c|}{0} & \multicolumn{2}{|c|}{0} & \multicolumn{2}{|c|}{0.25} & \multicolumn{2}{|c|}{0.375} & 0.525 \\
\hline \multicolumn{3}{|c|}{$\begin{array}{c}\text { Ventilation factor } \\
\qquad V_{f} / \mathrm{m}^{5 / 2}\end{array}$} & \multicolumn{2}{|c|}{2.18} & \multicolumn{2}{|c|}{1.93} & \multicolumn{2}{|c|}{1.62} & \multicolumn{2}{|c|}{1.4} & \multicolumn{2}{|c|}{1.05} & 0.68 \\
\hline \multicolumn{3}{|c|}{$\begin{array}{c}\text { Ambient air } \\
\text { temperature } \\
T_{o}{ }^{\circ} \mathrm{C} \\
\end{array}$} & 15 & 15 & 15 & 15 & 16 & 16 & 15 & 15 & 16 & 16 & 16 \\
\hline \multicolumn{3}{|c|}{$\begin{array}{c}\text { Burning time } \\
t_{B} / \mathrm{s}\end{array}$} & 621 & 488 & 472 & 556 & 547 & 524 & 566 & 531 & 452 & 422 & 608 \\
\hline \multicolumn{3}{|c|}{$\begin{array}{c}\text { Maximum heat } \\
\text { release rate measured } \\
\dot{q}_{\max } / \mathrm{kW}\end{array}$} & 2642 & 2632 & 2496 & 2460 & 2112 & 2354 & 1996 & 1776 & 1335 & 1306 & 934 \\
\hline \multicolumn{3}{|c|}{$\begin{array}{c}\text { Maximum gas } \\
\text { temperature } \\
T_{\text {fmax }} /{ }^{\circ} \mathrm{C} \\
\end{array}$} & 806 & 818 & 791 & 799 & 760 & 809 & 798 & 750 & 751 & 710 & 675 \\
\hline \multirow{7}{*}{$\begin{array}{c}m_{A} \\
/ \mathrm{kW} \cdot{ }^{\circ} \mathrm{C}^{-1}\end{array}$} & \multirow{2}{*}{$30 \%$} & $m_{A V}$ & 0.69 & 0.69 & 0.69 & 0.69 & 0.69 & 0.69 & 0.69 & 0.69 & 0.69 & 0.69 & 0.69 \\
\hline & & $m_{A}$ & 1.55 & 1.57 & 1.44 & 1.46 & 1.28 & 1.38 & 1.29 & 1.20 & 1.09 & 1.01 & 0.84 \\
\hline & \multirow{3}{*}{$50 \%$} & $m_{A V}$ & 1.14 & 1.14 & 1.01 & 1.01 & 0.85 & 0.85 & 0.74 & 0.74 & 0.55 & 0.55 & 0.36 \\
\hline & & $m_{A L}$ & 0.86 & 0.89 & 0.83 & 0.85 & 0.77 & 0.87 & 0.85 & 0.76 & 0.76 & 0.68 & 0.62 \\
\hline & & $m_{A}$ & 2.00 & 2.03 & 1.84 & 1.86 & 1.62 & 1.72 & 1.59 & 1.49 & 1.31 & 1.23 & 0.98 \\
\hline & \multirow{2}{*}{$70 \%$} & $m_{A V}$ & 1.60 & 1.60 & 1.42 & 1.42 & 1.19 & 1.19 & 1.03 & 1.03 & 0.77 & 0.77 & 0.50 \\
\hline & & $m_{A}$ & 2.46 & 2.49 & 2.25 & 2.27 & 1.96 & 2.06 & 1.88 & 1.78 & 1.53 & 1.45 & 1.12 \\
\hline \multirow{2}{*}{$\begin{array}{l}\text { Fitted } \\
\text { line }\end{array}$} & \multicolumn{2}{|c|}{$m_{f} / \mathrm{kW} \cdot{ }^{\circ} \mathrm{C}^{-1}$} & 3.09 & 3.09 & 2.65 & 2.85 & 2.50 & 2.50 & 2.37 & 2.28 & 1.93 & 1.89 & 1.65 \\
\hline & \multicolumn{2}{|c|}{$\mathrm{R}^{2}$} & 0.9133 & 0.9290 & 0.8590 & 0.8856 & 0.8050 & 0.8224 & 0.8512 & 0.8202 & 0.7626 & 0.7486 & 0.7374 \\
\hline
\end{tabular}




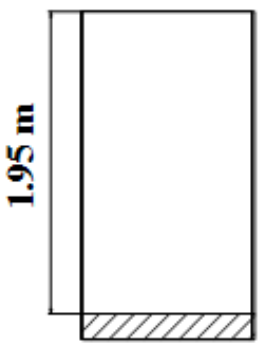

(a) Test A1

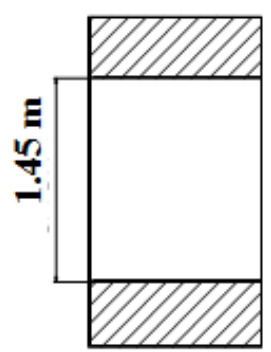

(d) Test A4

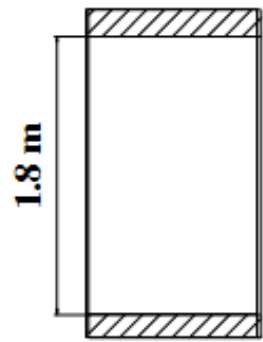

(b) Test A2

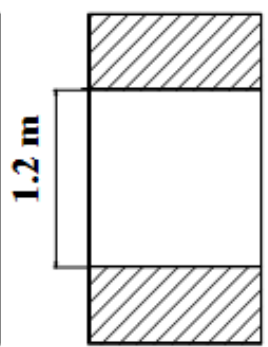

(e) Test A5

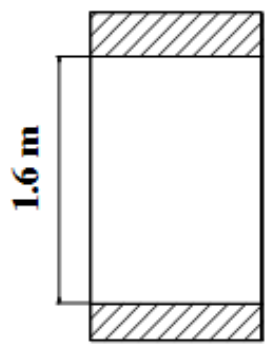

(c) Test A3

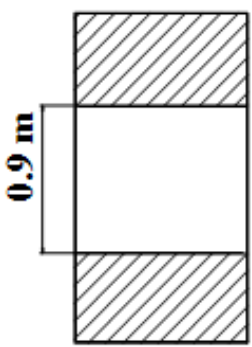

(f) Test A6

Fig. 2. Opening arrangements.

\section{GAS TEMPERATURES}

A thermal balance equation was proposed by Babrauskas [5,6] on the heat generation rate $\dot{q}$, air flow rate $\dot{m}_{a}$, fire temperature $T_{f}$, ambient air temperature $T_{o}$, heat lost $\dot{q}_{L}$ and specific heat capacity $C_{p}$ of air as:

$\dot{q}=\dot{m}_{a} C_{p}\left(T_{f}-T_{o}\right)+\dot{q}_{L}$

Note that $T_{f}$ is the flame temperature ejecting out of the opening. The gas temperature in the compartment near the ceiling is assumed to equal to $T_{f}$ for a post-flashover fire.

The heat generation term $\dot{q}$ can be expressed in terms of fuel mass loss rate $\dot{m}_{p}$ and effective calorific value $\Delta h_{c}$ as:

$\dot{q}=\dot{m}_{p} \Delta h_{c}$

The air flow rate through an opening of area $A_{v}$ and height $h_{v}$ is:

$\dot{m}_{a}=0.5 A_{v}\left(h_{v}\right)^{0.5}$

Note that $A_{v}\left(h_{v}\right)^{0.5}$ is the ventilation factor relating to $\dot{q}[5,6]$.

The heat loss can be expressed in terms of wall area $A_{w}$, gas emissitivity $\varepsilon_{f}$ of 0.5 and Stefan-Boltzman constant $\sigma$ of $5.67 \times 10^{-11} \mathrm{~kW} \cdot \mathrm{m}^{-2} \cdot \mathrm{K}^{-4}$.

$\dot{q}_{L}=\varepsilon_{f} \sigma\left(T_{f}^{4}-T_{o}^{4}\right)\left(0.4 A_{w}\right)$

This gives:

$\dot{q}=m_{A}\left(T_{f}-T_{o}\right)$ 
Note that there are two parts of the result $m_{A}$ as in the above equation.

$m_{A}=m_{A V}+m_{A L}$

The first part $m_{A V}$ is relating to ventilation provision given by Eq. 3. The second part $m_{A L}$ is related to heat lost given by Eq. 4.

$m_{A V}=0.5 A_{v} h_{v}^{0.5} C_{p}$

$m_{A L}=\varepsilon_{f} \sigma\left(0.4 A_{w}\right)\left(T_{f}+T_{o}\right)\left(T_{f}^{2}+T_{o}^{2}\right)$

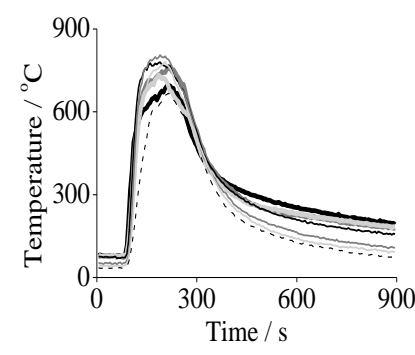

(a) Test A1a

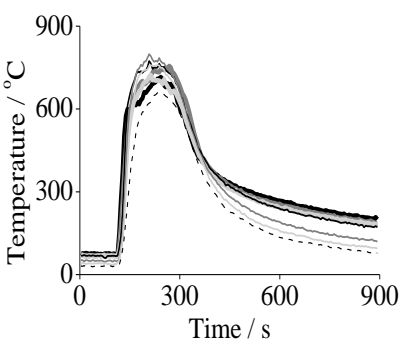

(d) Test A2b

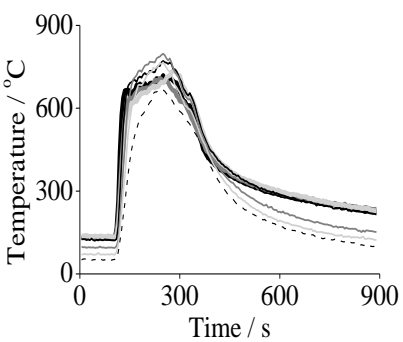

(g) Test A4a

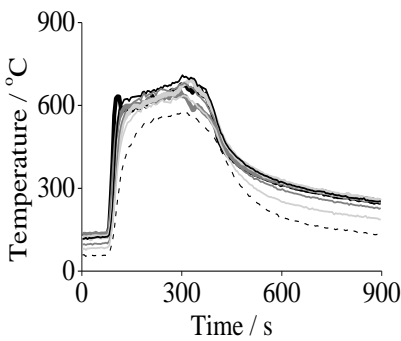

(j) Test A5b

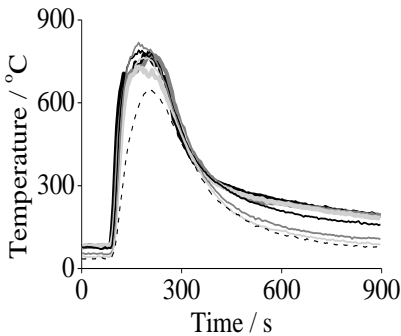

(b) Test A1b

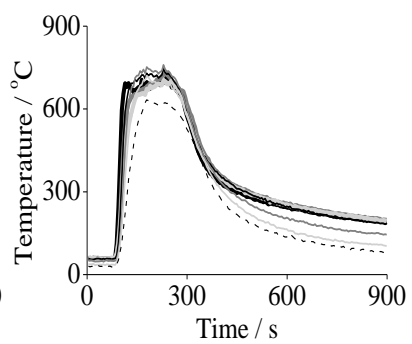

(e) Test A3a

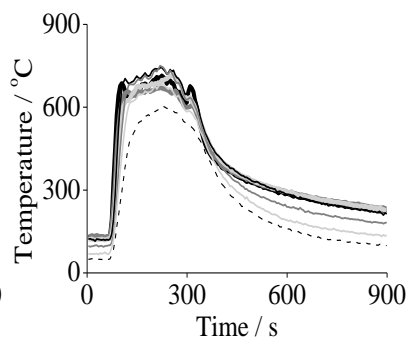

(h) Test A4b

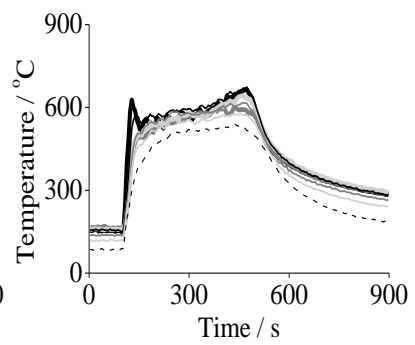

(k) Test A6

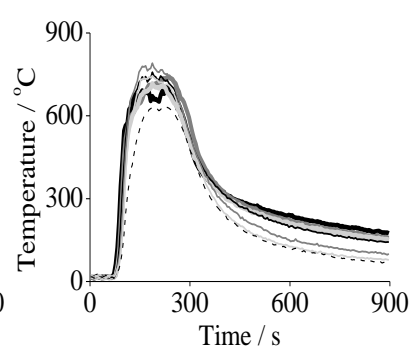

(c) Test A2a

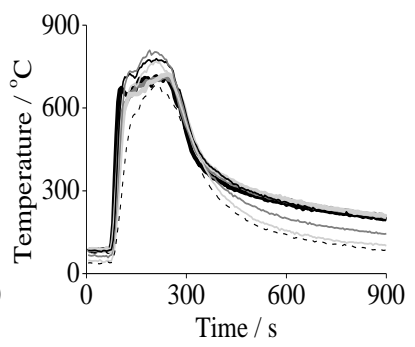

(f) Test A3b

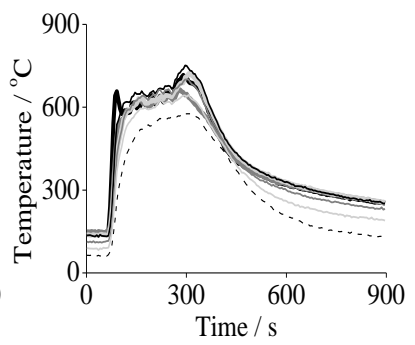

(i) Test A5a

Fig. 3. Measured gas temperatures. 
The values of $T_{f}$ were different for each test with $m_{A V}, m_{A L}$ and $m_{A}$ estimated separately. Further, the values of $A_{v}, h_{v}, A_{w}$, and $T_{o}$ were also different. Putting numerical values of $C_{p}$ of $1.05 \mathrm{~kJ} \cdot \mathrm{kg}^{-1} \cdot \mathrm{K}^{-1}$ and $V_{f}$, for example of $2.18 \mathrm{~m}^{5 / 2}$ as in Test Ala to Eq. $7, m_{A V}$ is $1.145 \mathrm{~kW} \cdot{ }^{\circ} \mathrm{C}^{-1}$. Putting $A_{w}$ of $44.52 \mathrm{~m}^{2}, \sigma$ of $5.67 \times 10^{-11} \mathrm{~kW} \cdot \mathrm{m}^{-2} \cdot \mathrm{K}^{-4}, \varepsilon_{f}$ of 0.5 as used before by Babrauskas and Williams [5] which was demonstrated to be a good estimation for calculating heat release rate, $T_{f}$ of $1079 \mathrm{~K}$ and $T_{0}$ of $288 \mathrm{~K}$ for Test A1a into Eq. 8 gives $m_{A L}$ of $0.86 \mathrm{~kW} \cdot{ }^{\circ} \mathrm{C}^{-1}$. Substituting $m_{A V}$ and $m_{A L}$ into Eq. 6 , this gives $m_{A}$ of $2.00 \mathrm{kWm}{ }^{-2}$.

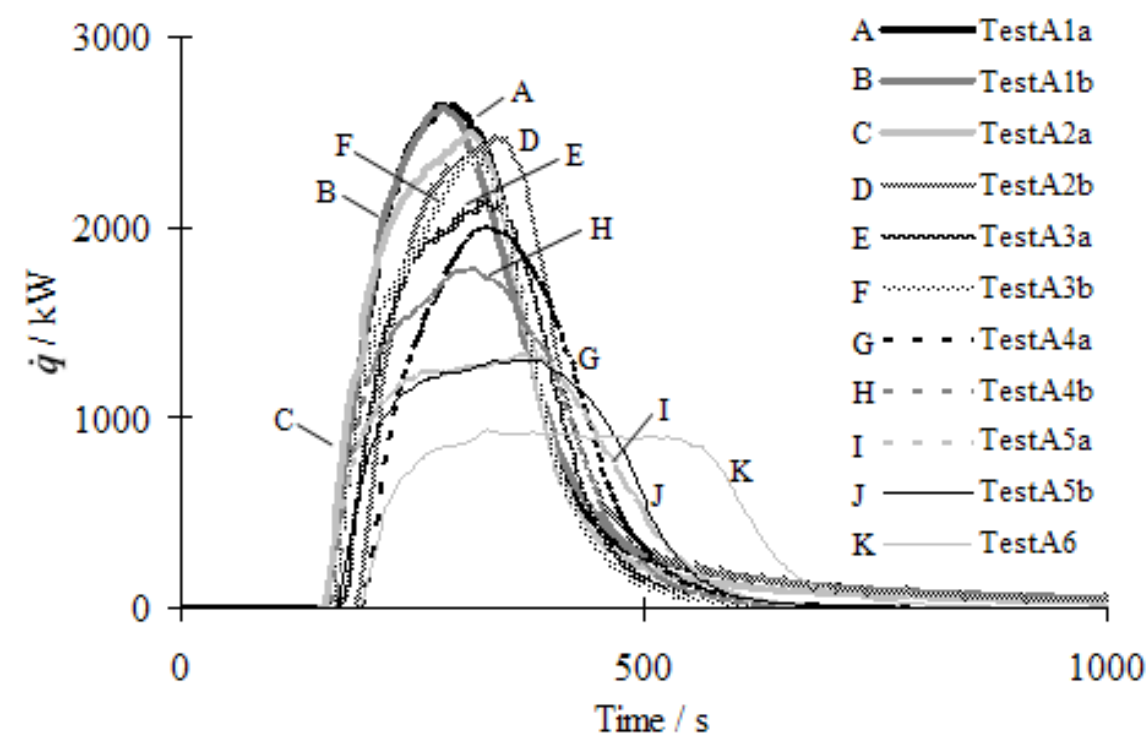

Fig. 4. Transient heat release rates.

\section{DISCUSSION}

Values of maximum heat release rate $\dot{q}_{\text {max }}$ for the tests are plotted against the maximum gas temperature rise $\left(T_{\text {fmax }}-T_{o}\right)$ among all measured 7 points at T1 to T4. Maximum gas temperature was at thermocouple T4b (position shown in Fig. 1) for tests A1a to A4b, and T4a for Tests A5b and A6. The following line of correlation coefficient $\mathrm{R}^{2}$ of 0.649 is fitted by the method of least square.

$\dot{q}_{\max }=2.97\left(T_{\text {fmax }}-T_{o}\right)$

Experimental data on $\dot{q}_{\max }$ and $\left(T_{f m a x}-T_{o}\right)$ and the above line are shown in Fig. 5. As shown in Table 1, the values of $m_{A}$ for the 6 sets of tests lie between $0.84 \mathrm{~kW} \cdot{ }^{\circ} \mathrm{C}^{-1}$ for Test $\mathrm{A} 6$ with $30 \%$ stoichiometric burning to $2.49 \mathrm{~kW} \cdot{ }^{\circ} \mathrm{C}^{-1}$ for Test A1b with $70 \%$ stoichiometric burning. Analytical results given by Eq. 5 with $m_{A}$ of $0.84 \mathrm{~kW} \cdot{ }^{\circ} \mathrm{C}^{-1} 2.49 \mathrm{~kW} \cdot{ }^{\circ} \mathrm{C}^{-1}$ are also plotted in Fig. 5 for comparison.

It is clearly observed that experimental heat release rates measured by the oxygen consumption method are much higher than the estimated values.

In addition, the transient values of $\dot{q}$ are plotted against the corresponding transient $\left(T_{f}-T_{o}\right)$ on the set of curve with $T_{\text {fmax }}$ for all six sets of tests. Again, these gas temperatures were measured at thermocouple T4b for Tests A1a to A4b, and T4a for Tests A5b and A6.

The following line fitted by the method of least square for each test with slope $m_{f}$ is found for the experimental data:

$\dot{q}=m_{f}\left(T_{f}-T_{o}\right)$ 
Values of $m_{f}$ and the corresponding correlation coefficient $\mathrm{R}^{2}$ for the six sets of tests are shown in Table 1. Values of $m_{f}$ are lying from $1.65 \mathrm{~kW} \cdot{ }^{\circ} \mathrm{C}^{-1}$ for test A6 to $3.09 \mathrm{~kW} \cdot{ }^{\circ} \mathrm{C}^{-1}$ for Tests A1a. These lines are plotted together with analytical results for each test given by Eq. 5 in Fig. 6.

The range of validity given by Eq. 6 for $m_{A}$ lying between $\left(0.6 m_{A V}+m_{A L}\right)$ and $\left(1.4 m_{A V}+m_{A L}\right)$ are also plotted in Fig. 6.

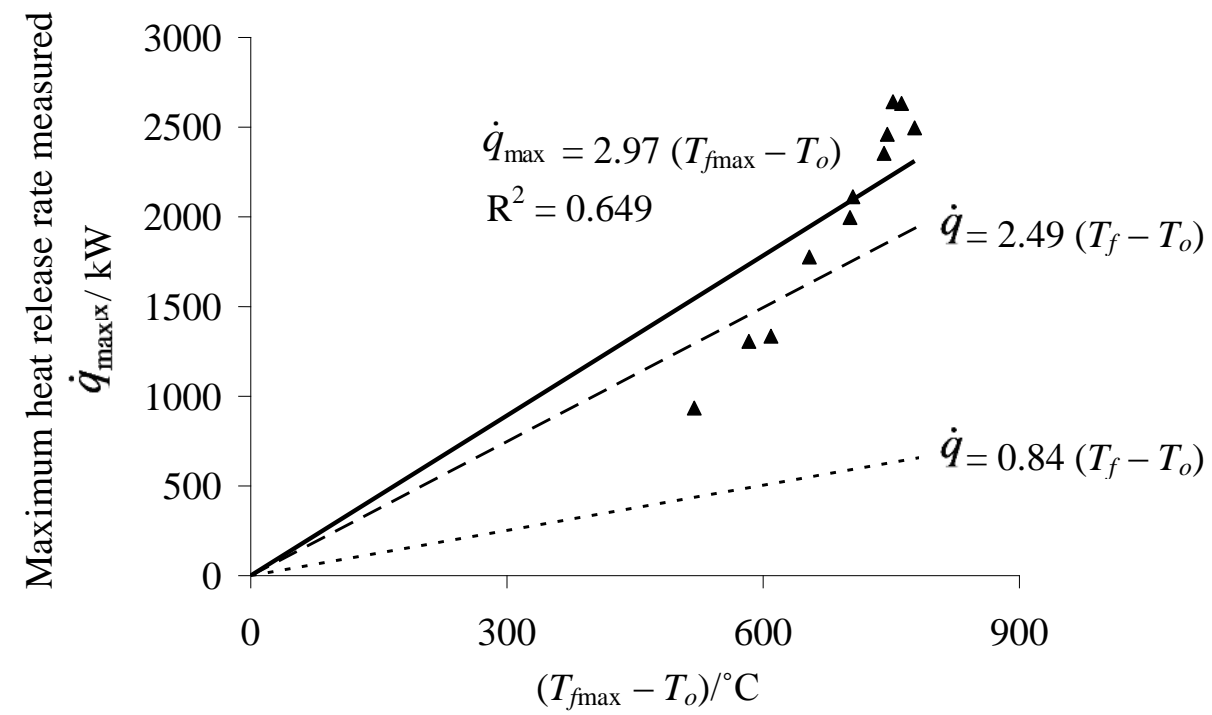

Fig. 5. Maximum heat release rate against maximum gas temperature.

In view of the above study, the thermal aspects on relating gas temperature with heat release rate measured by oxygen consumption calorimetry can be studied by the thermal balance equation. In general, heat release rates estimated by the analytical equation are smaller than experimental results. This is very obvious for the air flow rate through the door was estimated by Eq. 3. However, estimated heat release rate agreed better with experiment when the air intake rate is higher. The slope $m_{A}$ are closer to $m_{f}$ for higher air intake rate in view of Table 1.

\section{CONCLUSION}

Heat release rates for flashover fires in a small chamber were studied experimentally with oxygen consumption calorimetry. The correlation equations $[5,6]$ on relating the heat release rates to gas temperature at post-flashover fires were justified by full-scale burning tests at different ventilation factors. It is observed that the estimated heat release rates were lower than the experimental measurement. Air intake rate might be higher to give more oxygen for combustion. This point should be considered in applying empirical correlation for estimating heat release rate [14]. 


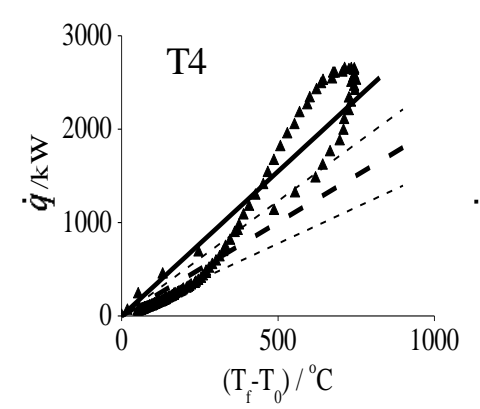

(a) Test A1a

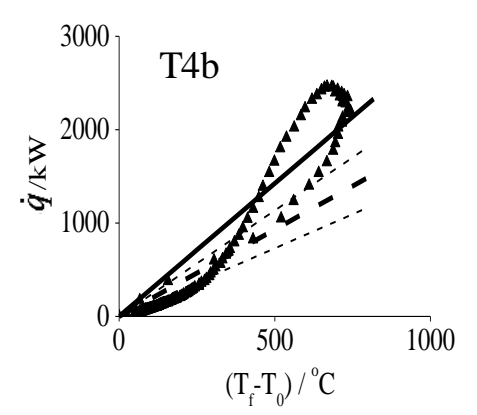

(d) Test A2b

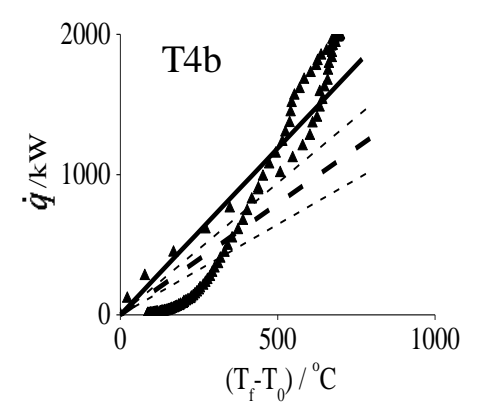

(g) Test A4a

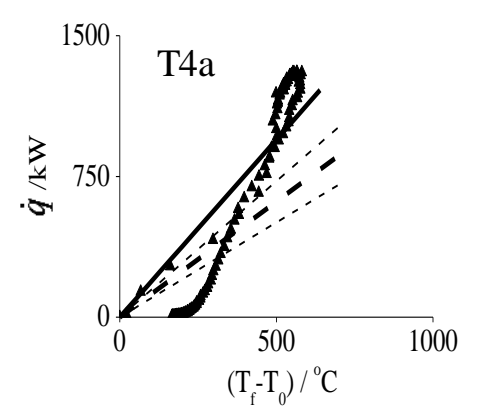

(j) Test A5b

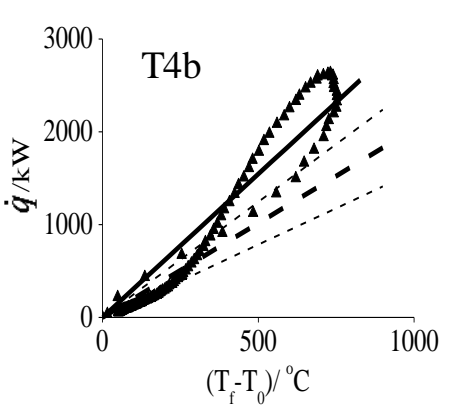

(b) Test A1b

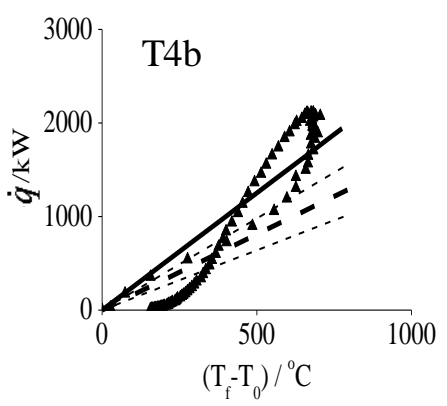

(e) Test A3a

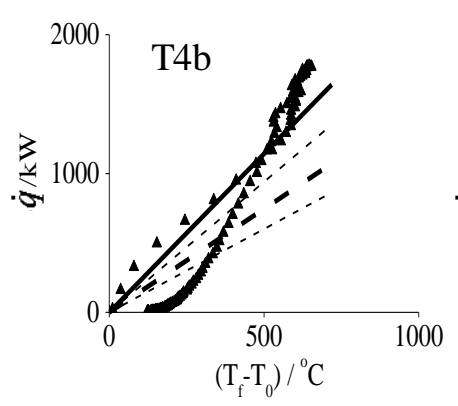

(h) Test A4b

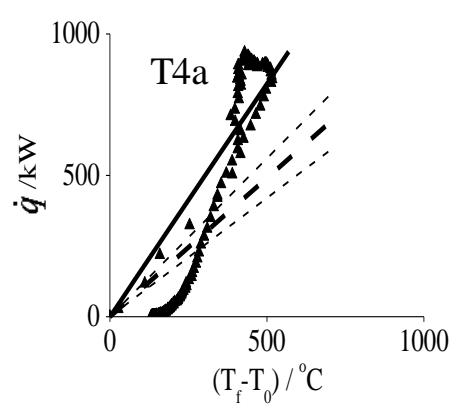

(k) Test A6

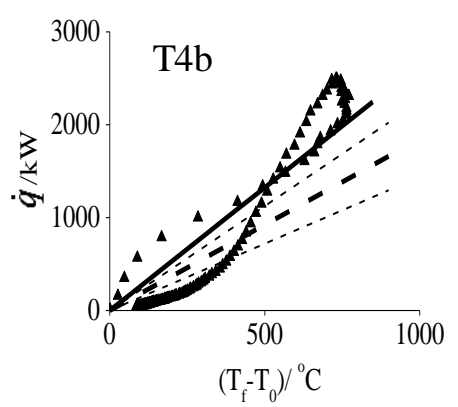

(c) Test A2a

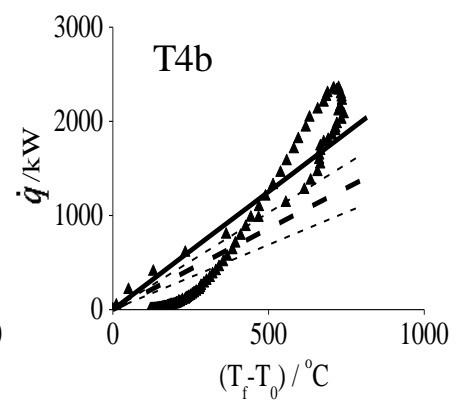

(f) Test A3b

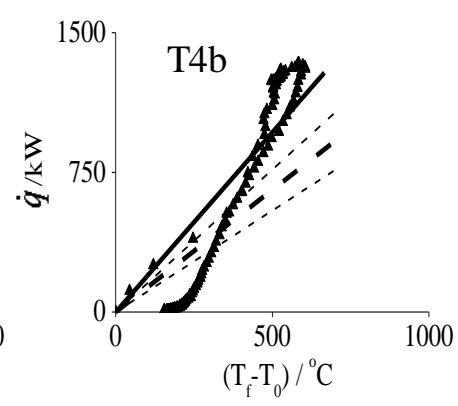

(i) Test A5a

$\Delta \quad$ Experimental

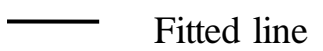

- - - Analytical line

-...- Range of validity

Fig. 6. Transient results on the set of data with maximum gas temperatures. 


\section{ACKNOWLEDGEMENT}

This work described in this paper was supported by a grant from the Research Grants Council of the Hong Kong Special Administrative Region, China for the project "Smoke Emission in Burning Fire Resisting Glass with Higher Rating" (PolyU 5145/07E) with account number B-Q05q.

\section{REFERENCES}

[1] Walton, W.D. and Thomas, P.H., "Estimating Temperatures in Compartment Fires," The SFPE Handbook of Fire Protection Engineering ( $I^{\text {st }} e d$.), DiNenno P.J. (ed.), National Fire Protection Association, Quincy, MA, 1988, p. 2/16-2/32.

[2] Chow, W.K., "Several Points to Note in Performance-based Design for Fire Safety Provisions in Hong Kong", Paper presented at The National Symposium on Fire Safety Science and Engineering, Beijing, China, 14-16 October 2010.

[3] Kawagoe, K., "Fire Behaviour in Rooms," Report No. 27, Building Research Institute, Tokyo, Japan, 1958.

[4] Rockett, J.A. (1976) Fire Induced Gas Flow in an Enclosure, Combustion Science and Technology 12: 165-175. http://dx.doi.org/10.1080/00102207608946717

[5] Babrauskas, V. and Williams, R.B., (1978) Post-flashover Compartment Fires: Basis of a Theoretical Model, Fire and Materials 2(2): 39-53. http://dx.doi.org/10.1002/fam.810020202

[6] Babrauskas, V., (1980) Estimating Room Flashover Potential, Fire Technology 16(2): 94-103. http://dx.doi.org/10.1007/BF02481843

[7] Babrauskas, V., and Grayson, S.J., Heat Release in Fires, Elsevier Applied Science, London and NY, 1992.

[8] Chow, W.K., Gao, Y., Dong, H., Zou, G.W., Luo, Z., and Meng, L., (2003) Experimental Studies on Minimum Heat Release Rates for Flashover with Oxygen Consumption Calorimetry, Architectural Science Review 46(3): 291-296.

[9] Thomas, P.H., Bullen, M.L., Quintiere, J.G., and McCaffrey, B.J., (1980) Flashover and Instabilities in Fire Behavior, Combustion and Flame 38: 159-171, http://dx.doi.org/10.1016/00102180(80)90048-6.

[10] Thomas, P.H., (1981) Testing Products and Materials for Their Contribution to Flashover in Rooms, Fire and Materials 5: 103-111, http://dx.doi.org/10.1002/fam.810050305.

[11] McCaffrey, B.J., Quintiere, J.G., and Harkleroad, M.F., (1981) Estimating Room Temperatures and the Likelihood of Flashover using Fire Data Correlations, Fire Technology 17(2): 98-119, http://dx.doi.org/10.1007/BF02479583.

[12] Quintiere, J.G., "Growth of Fire in Building Compartments," Fire Standards and Safety, ASTM STP 614, American Society for Testing and Materials, Philadelphia, USA, 1976, p. 131-167.

[13] Morgan, H.P., "The Influence of Window Flows in the Onset of Flashover," SFSE/FRS Symposium on Flow Through Openings, p. 1-21, 13 June 1989, Borehamwood, BRE, Garston, UK.

[14] Utiskul, Y. and Quintiere, J.G., 2009. An Application of Mass Loss Rate Model with Fuel Response Effects in Fully-developed Compartment Fires. Fire Safety Science 9: 827-838. http://dx.doi.org/ 10.3801/IAFSS.FSS.9-827 